Cita: Fernandes, R.; Oliveira, R.; Martins, A.; Paulo Brito, J. (2021). Internal training and match load quantification of one-match week schedules in female first league Portugal soccer team.

Cuadernos de Psicología del Deporte, 21(3), 126-138

\title{
Internal training and match load quantification of one-match week schedules in female first league Portugal soccer team
}

\section{Carga interna y cuantificación de la carga de entrenamiento de una semana de partido en una equipa femenina de fútbol de Portugal de la primera liga}

\section{Quantificação da carga interna de treino e de jogo em semanas com um} jogo numa equipa feminina de futebol da primeira liga portuguesa

\author{
Fernandes, Renato ${ }^{1,3,4}$, Oliveira, Rafael ${ }^{1,2,3}$, D. Martins, Alexandre ${ }^{1,3}$, Moreira de Brito, João ${ }^{1,2,3}$
}

${ }^{1}$ ESDRM-IPS - Sports Science School of Rio Maior - Polytechnic Institute of Santarém, Av. Dr. Mário Soares, 2040-413 Rio Maior, Portugal; ${ }^{2}$ CIDESD - Research Center in SportSciences, Health Sciences

and Human Development, Quinta de Prados, Edifício Ciências de Desporto, 5001-801, Vila Real, Portugal; ${ }^{3}$ CIEQV - Life Quality Research Centre, 2140-413, Rio Maior, Portugal; ${ }^{4}$ UTAD - University of Trás os Montes e Alto Douro, Quinta de Prados, 5000-801 Vila Real

\section{RESUMEN}

La cuantificación de la carga de entrenamiento (TL) permite a los entrenadores gestionar la carga durante el entrenamiento con el objetivo de estar en la mejor forma física para la próxima competición. El propósito de este estudio fue comparar la Percepción Subjetiva de Esfuerzo (s-RPE) y el Índice Hooper (HI) entre deportes y partidos de un solo equipo de fútbol de la principal liga femenina portuguesa. En este estudio participaron dieciséis jugadores con una media \pm DE edad, altura y peso de 24,0 $\pm 2,9$ años, $164 \pm 4,1 \mathrm{~cm}$ y 58,5 $\pm 8,2 \mathrm{~kg}$, respectivamente. Los participantes completaron $\geq 80 \%$ de las sesiones de entrenamiento durante la temporada 2019/20. Los datos evaluados fueron s-RPE y HI, que midieron la calidad de la grasa, la fatiga, el estrés y el dolor muscular (DOMS). Los datos se analizaron en relación con el número de días durante un microciclo competitivo (semana de juego), es decir, menos día de juego (MD-) con tres sesiones de entrenamiento por semana (MD-5; MD-4; MD-2). El estudio analizó datos para un total de 12 juegos y 45 sesiones de entrenamiento con ANOVA de medidas repetidas, $p \leq 0,05$. Los resultados mostraron diferencias entre MD-5 (85,2 $\pm 0,3 \mathrm{~min})$ vs MD-4 (87,2 $\pm 0,4 \mathrm{~min})$ vs MD-2 (80,6 $\pm 0.6 \mathrm{~min})$ vs MD $(62,8$ $\pm 4,9 \mathrm{~min})$, todos $\mathrm{p}<0,05$; s-RPE mostró valores más altos en MD-5 (503,8 $\pm 19,0$ ua) vs MD-4 (473,2 $\pm 14,8$ ua) vs MD-2 (362,1 $\pm 12,1$ ua) vs MD (468, $2 \pm 40,5$ ua); El HI mostró valores más altos en MD-5 (13,4 \pm 0,5ua) frente a 


\title{
Training and match load quantification in women soccer players
}

MD-4 (13,4 $\pm 0,4$ ua) frente a MD-2 (12,7 $\pm 0,5$ ua) frente a MD (11,9 $\pm 0,4 \mathrm{ua})$; DOMS reveló diferencias entre MD4 vs MD-2 (3,1 $\pm 0,2$ vs 2,7 $\pm 0,2 \mathrm{ua}), \mathrm{p}<0,05$. Se ha demostrado que existe una mayor carga de entrenamiento en el MD-5 y MD-4 en comparación con el MD-2. Los resultados de HI mostraron que la grasa, la fatiga, el estrés y DOMS estaban bien controlados por el equipo técnico y los jugadores.

Palabras clave: carga de entrenamiento, carga interna, fútbol europeo, índice de Hooper, s-RPE, atletas profesionales.

\begin{abstract}
Training load (TL) quantification allow coaches to a better load management during training sessions to be in the best physical fitness to the next match. The aim of this study was to compare session rated of perceived exertion (sRPE) and Hooper Index (HI) between training and match days from the same women's Portuguese League team. Sixteen players with a mean \pm SD age, height and weight of $24.0 \pm 2.9$ years, $164 \pm 4.1 \mathrm{~cm}$ and $58.5 \pm 8.2 \mathrm{~kg}$, respectively, participated in this study. The participants completed $\geq 80 \%$ of the training sessions during $2019 / 20$ in-season. Data was collected through the s-RPE and the HI that measured sleep quality, fatigue, stress, and muscle soreness (DOMS). Data was analysed in relation to the number of days away from the competitive one-match week (i.e., match day minus, MD-) with three training sessions a week (MD-5; MD-4; MD-2). The study analysed data from a total of 12 matches and 45 training sessions with repeated measures ANOVA, $\mathrm{p} \leq 0.05$. Results showed differences between MD5 (85.2 $\pm 0.3 \mathrm{~min})$ vs MD-4 (87.2 $\pm 0.4 \mathrm{~min})$ vs MD-2 (80.6 $\pm 0.6 \mathrm{~min})$ vs MD $(62.8 \pm 4.9 \mathrm{~min})$, all p $<0.05$; s-RPE showed higher values on MD-5 (503.8 $\pm 19.0 \mathrm{au})$ vs MD-4 (473.2 $\pm 14.8 \mathrm{au})$ vs MD-2 (362.1 $\pm 12.1 \mathrm{au})$ vs MD (468.2 $\pm 40.5 \mathrm{au})$;

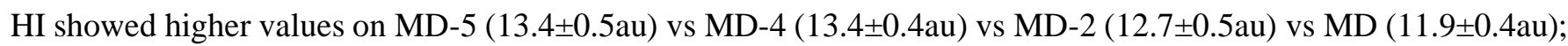
DOMS revealed difference between MD-4 vs MD-2 (3.1 \pm 0.2 vs $2.7 \pm 0.2 \mathrm{au}), \mathrm{p}<0.05$. It was shown that there is a higher TL on MD-5 and MD-4 compared with MD-2. Results from HI showed that sleep, fatigue, stress and DOMS was well fair controlled by coaches and staff.
\end{abstract}

Keywords: training load, internal load, European football, Hooper index, s-RPE, professional athletes.

\section{RESUMO}

A quantificação da carga de treino (CT) permite aos treinadores uma melhor gestão da carga dos jogadores durante as sessões de treino para que estejam na melhor condição física para o próximo jogo. O objetivo deste estudo foi comparar os valores da perceção subjetiva de esforço (s-RPE) e o Índice Hooper (HI) entre dias de treino e de jogo numa equipa feminina de Futebol da principal Liga feminina portuguesa. Participaram neste estudo dezasseis jogadoras com média \pm DP de idade, altura e peso de 24,0 $\pm 2,9$ anos, $164 \pm 4,1 \mathrm{~cm}$ e 58,5 $\pm 8,2 \mathrm{~kg}$, respetivamente. As participantes completaram $\geq 80 \%$ das sessões de treino durante a temporada de $2019 / 20$. Os dados avaliados foram o s-RPE e o HI que mediu a qualidade do sono, fadiga, stresse e dor muscular (DOMS). Os dados foram recolhidos através do s-RPE e do IH que avaliaram a qualidade do sono, fadiga, stress e dor muscular (DOMS). Os dados foram analisados em relação ao número de dias para o jogo competitivo (ou seja, dia de jogo menos, MD-) com três sessões de treino por semana (MD-5; MD-4; MD-2). O estudo analisou 12 jogos e 45 sessões de treino através de medidas repetidas ANOVA, $p \leq 0,05$. Os resultados mostraram diferenças entre MD-5 (85,2 $\pm 0,3 \mathrm{~min})$ vs MD-4 (87,2 $\pm 0,4 \mathrm{~min})$ vs MD-2 $(80,6 \pm 0,6 \mathrm{~min})$ vs MD $(62,8 \pm 4,9 \mathrm{~min})$, todos $\mathrm{p}<0,05$; s-RPE mostrou valores mais altos em MD-5 $(503,8 \pm 19,0 \mathrm{au})$ vs MD-4 (473,2 $\pm 14,8 \mathrm{au})$ vs MD-2 (362,1 $\pm 12,1 \mathrm{au})$ vs MD $(468,2 \pm 40,5 \mathrm{au})$; HI mostrou valores mais

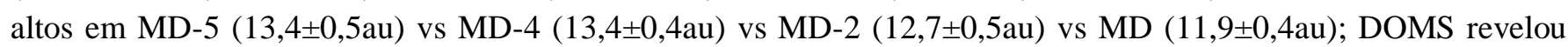
diferença entre MD-4 vs MD-2 (3,1 $\pm 0,2$ vs $2,7 \pm 0,2 \mathrm{au}), \mathrm{p}<0,05$. Foi demonstrado que existe uma maior CT no MD5 e MD-4 em comparação com o MD-2. Os resultados do HI mostraram que o sono, fadiga, stress e DOMS foi bem controlado pelos treinadores e staff.

Palavras chave: carga de treino; carga interna; futebol europeu; índice de Hooper; s-RPE; atletas 


\section{Fernandes, R.; Oliveira, R.; Martins, A.; Paulo Brito, J.}

\section{INTRODUCTION}

Soccer is considered one of the most popular sports worldwide and surely the most famous in Europe. Female soccer has been growing its popularity, especially on the last two decades where professionalism has increased markedly, with elite players now employed on either a professional or semi-professional basis (Datson, et al., 2014). There is an abundance of research on the physical aspects of male soccer (e.g., match analysis, fitness characteristics, and training patterns) but yet research on the female game is largely confined to match analysis of elite senior competition and fitness characteristics (Alexiou \& Coutts, 2008; Andersson et al 2010; Mohr et al, 2008; Krustrup et al, 2010; Datson et al, 2018; Emmonds et al, 2018). Currently, elite women's soccer players are exposed to greater training volume and competition demands than ever before. Consequently, these increased physical requirements may have implications for both physical performance levels, injury patterns and on athlete's wellness. Training load (TL) quantification allow coaches and staff to better manage load during training sessions to avoid cumulative fatigue, higher risk of injury and to best prepare the athlete's physical fitness to the next match (Oliveira et al., 2020; 2019a, 2019b; Halperin \& Emanuel, 2020; Ehrmann et al., 2016; Peart et al., 2018). Therefore, nowadays it is critical to quantify internal training and match load on women's soccer to provide data to the practitioners and technical staff, to allow for better planning, periodization, assessment and workload control (McLaren, Smith, Spears, \& Weston, 2016). The ability to recover between bouts of high intensity activity and subsequently, repeating these efforts has been reported as a critical physical ability of modernday soccer players (Gabbett \& Mulvey, 2008). Consequently, the physical preparation of elite women soccer players has become an important component of professional training to deal with the increasing energy demands of match play (Krustrup et al., 2005; Carling et al., 2008; Iaia et al., 2009; Peart et al., 2018). To optimize athletic performance, physical training should be prescribed to suit each athlete's individual characteristics. However, in team sports like soccer, training sessions are often conducted in a group, which reduces the likelihood that players are receiving specific training based on their individual characteristics (Impellizzeri et al., 2005). For example, some authors (Arcos et al., 2016; Benjamin et al., 2020; Clemente et al., 2017; Emmonds et al., 2018) demonstrated that soccer players with superior fitness levels did not receive sufficient training stimulus to further increase their fitness when training in a team environment using small-sided games alone. It has also been suggested that players with inferior fitness levels may be overstressed during team-based training sessions leading to increased fatigue, injury, and a reduction in performance (Krustrup et al., 2010; Giménez et al., 2019, Ehrmann et al., 2018). These findings may suggest that individuals within the same soccer team may not receive an appropriate level of training stimulus when a team-based training approach is undertaken. Therefore, to overcome the limitations associated with team-based training, it has been suggested that a simple system that quantifies an individual's response to training (ie, internal TL) is developed, so that coaches can monitor and modify training according to individual players' needs (Chen et al., 2010; Impellizzeri et al., 2019; Foster et al., 2001). The assessment of internal TL requires quantification of the intensity and duration of the physiological stress imposed on the athlete (Foster et al., 2001; Foster, 1998). Over the last decade, rated of Perceived Exertion (RPE) has shown to be a good method of assessing the internal load in soccer players (Gaudino, et al., 2015; Arcos, Méndez-Villanueva, Yanci, \& Martínez-Santos, 2016), however, about women's soccer, information has still been scarce although scientific literature on women soccer athletes is growing (Alexiou \& Coutts, 2008). Understanding the internal response to external loads placed upon players is particularly relevant to practitioners (Impellizzeri et al., 2019; Mclaren et al., 2017). Internal response to training can be measured practically using session-RPE (s-RPE), which provide 


\section{Training and match load quantification in women soccer players}

a valid quantification of relative exercise intensity and internal load across a range of exercise modalities (Chen et al., 2010; Scantlebury et al., 2017). This method is also cost- and time-effective, allowing to monitor internal TL in clubs where resources can be limited (Wright et al, 2020).

The attention given to the post-match and training sessions recovery status of soccer players has been increasing recently (Thorpe et al., 2015, 2016a, 2016b; Rabbani et al., 2019). Tracking recovery of soccer players requires monitoring tools that are sensitive to match and training sessions fatigue to help practitioners making decisions on a daily basis (Thorpe et al., 2016b). Hooper index (HI) is another easy-to-use, non-cost, and non-invasive monitoring tool that allow to monitor the players' recovery and wellness (Hooper \& Mackinnon, 1995). HI seems promising for tracking fatigue during in the season in professional soccer (Rabbani et al, 2019). HI has been reported in recent literature as a reliable method for the monitoring of athlete wellness providing further information concerning the detail of player fatigue, stress, muscle soreness and sleep perception and it has been used in a large number of soccer studies (Clemente, et al., 2017, 2019; Moalla et al., 2016; Oliveira et al., 2020, 2019a, 2019b; Rabbani et al., 2019; Thorpe et al., 2016a, 2016b).

However, compared to internal measures, such as heart rate (HR), RPE and to the best of author's knowledge, HI has been little used in elite women's soccer as a measure of athlete recovery and wellness. Thus, the aim of this study was to analyse and compare s-RPE and HI between training sessions and match days from a women's Portuguese BPI League team. It is intended to get information of TL organization that coaches and researchers may use to help design and implement optimal training programs for appropriate physical fitness development in female professional soccer players, without causing negative disturbances.

\section{MATERIAL AND METHODS}

Participants
Sixteen players with a mean \pm SD age, height, weight and body mass index of $24.0 \pm 2.9$ years, $164.3 \pm 4.1 \mathrm{~cm}$, $58.5 \pm 8.2 \mathrm{~kg}$, and $23.3 \pm 4.3 \mathrm{~km} / \mathrm{m}^{2}$, respectively, participated in this study. The players belong to a team that participated in the Portuguese BPI League in the $2019 / 20$ season. The participants completed $\geq 80 \%$ of the training sessions during 2019/20 in-season, from the beginning of the season (September 2019) until the championship stopped on $11^{\text {th }}$ March 2020 due to the COVID-19 pandemic. The exclusion criteria were to get injured, ill, sick, and not performing all assessments. The field positions of the players in the study consisted of three central defenders (CD), three wide defenders (WD), three central midfielders (CM), four wide midfielders (WM) and three strikers (ST) (Oliveira et al., 2020, 2019b). All participants were familiarized with the instruments and the protocols prior to the investigation and gave their written informed consent to be included in the project. This study was conducted according to the requirements of the Declaration of Helsinki and was approved by Ethics Committee of Polytechnic Institute of Santarém (252020Desporto).

\section{Procedures}

The training sessions were performed during a sixmonth period, from September to 11 March (early to mid-season). A total of 12 matches and 45 training sessions were performed. The training hours were from $8 \mathrm{pm}$ to $9: 30 \mathrm{pm}$. Usually, the games were at 3 $\mathrm{pm}$ on Sunday, however, and due to television broadcasts, they could sometimes be at $3 \mathrm{pm}$ on Saturday or at 11 am on Sunday.

Data were collected through the s-RPE and the HI that measured quality of sleep, fatigue, stress, and muscle soreness (DOMS). Data from goalkeepers was excluded. Data was analysed in relation to the number of days away from the competitive one-match week (i.e., match day minus, MD-) where the team trained three days a week (MD-5; MD-4; MD-2). This approach was also used in our previous studies (Alexiou \& Coutts, 2008; Clemente, et al., 2017; Malone et al., 2015; Oliveira et al., 2020, 2019a, 2019b). 


\section{Fernandes, R.; Oliveira, R.; Martins, A.; Paulo Brito, J.}

\section{Internal TL}

Thirty minutes following the end of each training session and match, players were asked to provide a RPE, 0-10 scale (Borg, 1970). Then, RPE was multiplied by training or match duration, respectively to generate s-RPE (Foster et al., 2001, 1998). Further descriptions on the use of s-RPE are described in previous studies (Clemente et al., 2017; Oliveira et al., 2020, 2019a, 2019b).

To assess the HI data, each player was asked to provide the scores approximately $30 \mathrm{~min}$ before each training session. The $\mathrm{HI}$ is the summation of four subjective ratings expressed in categories: fatigue, stress, muscle soreness and quality of sleep of the night that preceded the evaluation. Further descriptions on the use of $\mathrm{HI}$ are described in previous studies (Clemente et al., 2017; Oliveira et al., 2020, 2019a, 2019b).

\section{Statistical procedures}

Data were analysed using SPSS version 22.0 (SPSS Inc., Chicago, IL) for Windows statistical software package. Initially descriptive statistics were used to describe and characterize the sample. Shapiro-Wilk and Mauchly's tests were used to assumption normality and sphericity, respectively. Repeated measures ANOVA was used with Tukey' $b$ post hoc, once variables obtained normal distribution (Shapiro Wilk> 0.05), to compare days away from the competitive match fixture. Also, ANOVA Friedman and Mann-Whitney tests were used for the variables that not obtained normal distribution to compare different moments. Results were significant in the interaction $(\mathrm{p} \leq 0.05)$. The effect-size (ES) statistic was calculated to determine the magnitude of effects by standardizing the coefficients according to the appropriate between-subjects standard deviation and was assessed using the following criteria: $<0.2=$ trivial, 0.2 to $0.6=$ small effect, 0.6 to $1.2=$ moderate effect, 1.2 to $2.0=$ large effect and $>2.0=$ very large (Hopkins et al., 2009).

\section{RESULTS}

A total of sixteen elite women soccer players from the same team participated in the Portuguese BPI League in the 2019/20 season. Table 1 summarizes the characteristics and comparisons of the study sample in training and match days.

Table 1: TL during the MD minus for squad average, mean \pm SD.

\begin{tabular}{cccc}
\hline MD & RPE (AU) & Training Duration (min) & s-RPE (AU) \\
\hline MD-5 & $5.92 \pm 0.85^{\mathbf{b}, \mathbf{c}}$ & $85.18 \pm 1.21^{\mathbf{a}, \mathbf{b}, \mathbf{c}}$ & $504.60 \pm 76.94^{\mathbf{b}}$ \\
MD-4 & $5.45 \pm 0.65^{\mathbf{b , c}}$ & $87.16 \pm 1.29^{\mathbf{b}, \mathbf{c}}$ & $474.23 \pm 56.15^{\mathbf{b}}$ \\
MD-3 & & Day-off & \\
MD-2 & $4.45 \pm 0.69^{\mathbf{c}}$ & $80.58 \pm 2.26$ & $359.46 \pm 57.21$ \\
MD-1 & & Day-off & \\
MD & $7.04 \pm 1.55$ & $63.00 \pm 24.69$ & $465.71 \pm 223.90$ \\
\hline
\end{tabular}

MD- = match-day minus; RPE = rating of perceived exertion; $\mathrm{s}-\mathrm{RPE}=$ session rating of perceived exertion; $\mathrm{AU}=$ arbitrary units; $\mathrm{min}=$ minutes;

a-denotes differences with MD-4; b- denotes differences with MD-2; c- denotes differences with MD; $\mathrm{p}<0.05$. 


\section{Training and match load quantification in women soccer players}

Regarding RPE, results showed differences between MD-5 vs MD-2 ( $\mathrm{p}<0.001 ; \mathrm{g}=1.85[1.07,2.71])$ and MD-5 vs MD ( $\mathrm{p}=0.027 ; \mathrm{g}=-0.87[-1.59,-0.18])$. Also, MD-4 showed differences between MD-2 ( $\mathrm{p}=0.001$; $\mathrm{g}=1.45[0.71,2.24])$ and MD-4 vs MD $(\mathrm{p}=0.003 ; \mathrm{g}=$ $1.30[-2.01,-0.58])$. MD-2 showed difference between $\mathrm{MD}(\mathrm{p}<0.001 ; \mathrm{g}=-2.10[-3.00,-1.29])$.

In training duration, there were differences between MD-5 vs MD-4 ( $\mathrm{p}=0.020 ; \mathrm{g}=-1.54[-2.34,-0.79])$,
MD-5 vs MD-2 ( $<<0.001 ; \mathrm{g}=2.47[1.61,3.44])$ and MD-5 vs MD ( $\mathrm{p}=0.011 ; \mathrm{g}=1.23$ [0.52, 2.00]). Also, there were differences between MD-4 vs MD-2 $(\mathrm{p}<0.001 ; \mathrm{g}=3.49[2.46,4.66])$ and $\mathrm{MD}-4$ vs $\mathrm{MD}$ $(\mathrm{p}=0.006 ; \mathrm{g}=1.34[0.62,2.12])$.

In addition, there were differences between MD-5 vs MD-2 ( $<<0.001 ; \mathrm{g}=2.09[1.27,2.98])$ and MD-4 vs MD-2 ( $<<0.001 ; g=1.97[1.18,2.84])$ for $s-R P E$.

Table 2: HI during the MD minus for squad average, mean \pm SD.

\begin{tabular}{|c|c|c|c|c|c|}
\hline MD & Fatigue (AU) & Stress (AU) & DOMS (AU) & Sleep Quality (AU) & $\mathrm{HI}(\mathrm{AU})$ \\
\hline MD-5 & $3.34 \pm 0.68$ & $3.56 \pm 0.95$ & $2.88 \pm 0.82$ & $3.51 \pm 0.77$ & $13.30 \pm 2.01$ \\
\hline MD-4 & $3.55 \pm 0.56^{\mathrm{c}}$ & $3.34 \pm 0.89$ & $3.09 \pm 0.66^{\mathbf{b}}$ & $3.44 \pm 0.53$ & $13.45 \pm 1.69^{c}$ \\
\hline MD-3 & & & Day-off & & \\
\hline MD-2 & $3.32 \pm 0.55$ & $3.18 \pm 0.96$ & $2.75 \pm 0.61$ & $3.32 \pm 0.54$ & $12.59 \pm 1.86$ \\
\hline MD-1 & & & Day-off & & \\
\hline MD & $3.02 \pm 0.43$ & $3.01 \pm 0.64$ & $3.01 \pm 0.51$ & $3.21 \pm 0.61$ & $11.80 \pm 2.04$ \\
\hline
\end{tabular}

MD- = match-day minus; $\mathrm{HI}=$ Hooper Index;AU = arbitrary units; min=minutes; $\mathrm{HI}=$ Hooper index;

DOMS $=$ muscle soreness; $b$ - denotes differences with MD-2; $c$ - denotes differences with MD; $p<0.05$.

Regarding HI categories, there were significant differences between MD-4 vs MD ( $\mathrm{p}=0.049 ; \mathrm{g}=1.03$ $[0.33,1.77])$ for fatigue, between MD-4 vs MD-2 $(\mathrm{p}=0.040 ; \mathrm{g}=0.52[-0.15,1.21])$ for DOMS and between MD-4 vs MD ( $\mathrm{p}=0.042 ; \mathrm{g}=0.86[0.16,1.58])$ for total HI.

\section{DISCUSSION}

In this study, the aim was to analyse and compare the internal TL between training sessions and match-days from the same women's Portuguese League team. It is noteworthy to report that soccer team used for this study was consistently ranked among the top five seeds in the national Women's Soccer League (BPI League).

Our results showed that there are substantial differences for RPE and s-RPE when comparing training sessions, MD-5> MD-4> MD-2. Regarding RPE, there was a decrease over the training microcycle, with differences between MD-5 and MD4 compare with MD-2 and between MD-5, MD-4 and MD-2 compare with MD. In terms of training methodology and periodization, there would be a pattern in the microcycle. The pattern on the three training sessions was usually composed of a first training session (MD-5) in which the exercises of small-sided games, exercises of ball possession games and the circuits of specific strength and specific resistance were predominated. In MD-4, it was used exercises that requested higher intensities of aerobic resistance training, with the tactical games with larger spaces and a higher number of players. Finally, in MD2 , standardized exercises and the achievement of the goal were sought, fundamentally with the use of a few athletes and, consequently, requesting the use of speed, acceleration, and speed on the skills execution.

Regarding the s-RPE, there was also a decrease in TL over the microcycle, with differences between MD-5 


\section{Fernandes, R.; Oliveira, R.; Martins, A.; Paulo Brito, J.}

and MD-4 compare with MD. From the authors' knowledge there was a paucity in studies that address the weekly training load distribution pattern in female's soccer, however the results found are in line with those reported in male's soccer (Malone et al., 2015; Stevens et al., 2017; Oliveira et al., 2020, 2019a, 2019b).

The RPE values obtained are higher in matches, revealing that the matches' internal loads are the stimulus with the greatest impact on the perceived fatigue of the players, although $\mathrm{HI}$ did not present higher values in the following day of the match. According to these results, matches were rated hard to very hard, which corroborates those presented by Wright et al. (2020) who also stated that compared to matches, soccer training sessions were rated substantially easier for all exertion types. The fact that the training sessions' RPE was lower than matches are in accordance with results of both female's and male's soccer studies, which reported that the training sessions intensity is lower than matches intensity (Wright et al., 2020; Malone et al., 2015; Stevens et al., 2017; Oliveira et al., 2020, 2019a, 2019b).

A relevant observation was the fact that the matches' RPE values present a higher standard deviation which may be explained by less player effort due to their field 'position, status (starter, non-starter) or, due to the fact that there were differences in the perception that each one has in relation to their general physical condition response to the effort made.

The same pattern as RPE was not found in s-RPE, in which the match presents lower values, although not statistically significant. Interestingly, regarding s-RPE values, there were no differences between MD-5, MD4 and MD. These results were not usual in the literature on male teams (Thorpe et al., 2016; Stevens et al., 2017; Oliveira et al., 2019a), but this may be due to the number of weekly training sessions for female teams is inferior to that of the male teams. However, the literature available with female soccer suggested that, in relative terms, physiological demands (percentage of heart rate and percentage of $\mathrm{VO}_{2 \max }$ ) during match-play were similar to those obtained for male soccer (Stolen et al., 2005). However, Krustrup et al. (2010) observed an average reduction of more than $4 \%$ for most starters in elite female soccer matches. The observed decrement appears to be somewhat higher than the $2-3 \%$ reduction determined for male players (Krustrup et al., 2006; Mohr et al., 2004; Rebelo et al., 1998), which may be because the study investigated sprint performance after competitive matches and not friendly matches as in the other studies (Krustrup et al., 2010). Moreover, it could also be due to differences in training status or gender-specific fatigue development (Kent-Braun et al., 2002).

Regarding training duration, differences along the microcycle MD-4 > MD-5>MD-2 > MD were observed. These findings were probably due to the training planning and periodization strategy performed by the coach who privileges the MD-5 with high-intensity activities, like small-sided games that require more training duration. From the information provided to us by the team coach, in MD-4, the training session privileged low volume exercises to stimulate aerobic capacity and focus on tactical team issues to develop the squad' match model. The MD-2, last training of the week, was characterized by incorporating exercises that privilege sprint and short high-speed runs in low volume short game situations with the intention of preparing the squad for the match.

To the authors' knowledge, this is the first study investigating the variance of $\mathrm{HI}$ across microcycles in elite female professional soccer players. Although some authors (Scott et al., 2020) claimed that the ordinal wellness ratings do not meaningfully report to within-player previous or subsequent external loads in training or matches, numerous authors (Alexiou \& Coutts, 2008; Rabbani et al., 2019; Los Arcos et al., 2016; Polito et al., 2017; Clemente et al., 2017; Oliveira et al., 2020, 2019a, 2019b; Impellizzeri et al., 2019) claimed that the HI showed to be a useful measure for monitoring match- and training load- 


\section{Training and match load quantification in women soccer players}

induced fatigue in soccer players. In the present study, the results of the HI indicated that fatigue, DOMS and total HI were highest on MD-4. Ispirlidis et al. (2008) reported significant decreases in performance and biological alterations up to 72 hours after soccer matches, which corroborates with the highest fatigue, stress and sleep quality levels on MD-5 and MD-4.

In general, Hooper's categories indicated good mean levels, with low DOMS. As far as we know, there are no studies with reference to $\mathrm{HI}$ in female soccer players. When compared to female basketball players (Clemente et al., 2019), the present values are higher, which indicates that soccer players had less recovery capacity, although they had fewer weekly training sessions than the basketball players in the study by Clemente et al. (2019). The same study analyzed the internal load during training sessions that occurred two or three days before a match. In our study results indicated higher internal loads during training sessions that occurred on MD-4, which was the session training with more significant differences, either with MD-2 (DOMS) or with the match (fatigue and total HI). These data could show that regarding fatigue and DOMS, the MD-5 and MD-4 training were very close to each other regarding to the time variable, as there was only one day between the two, it could show an error in the planning and periodization of training although, in most cases, it is not the responsibility of the technical team as they feel obliged to train these days due to the club conditions and limited facilities that clubs offer to their teams. However, from the analysis of weekly TL distribution, it appeared that there was a load decrease (tapering phase) in the last training session before a match (MD-2), which was accompanied by an increase in wellness status on a match day.

In general, Hooper's categories indicated good mean levels, with very low DOMS, stress, and fatigue and very good sleep quality. The results of this study corroborate with Manzi et al. (2010), who reported the use of a tapering strategy before matches in professional basketball, with lower s-RPEs on the day before a match. It was noteworthy that Manzi et al. (2010) and Clemente et al. (2019) showed higher loads in some training sessions a s-RPE of approximately, 600-800 AU, while the average s-RPE of the present study is lower. Although wellness status can be influenced by extra-training factors (Haddad et al., 2013; Hooper and Mackinnon, 1995; Scott et al., 2020), the tapering phases before matches may have contributed to improve players' overall wellness, since the load decrease on the day before a match was accompanied by improvements in the players' total HI, DOMS, fatigue, and sleep quality on a MD. Due to differences between sports (soccer vs. basketball), future studies should investigate the impact of the training session and matches per week on soccer players' performance, as well as the relationship between wellness status and sport performance.

The results from the present study should not be generalized because it has been reported that a higher workload is performed by players at higher competition level compared with players at moderate levels in female players (Mohr et al., 2008; Mohr et al., 2004; Gabbett \& Mulvey, 2008) and the analyzed games are of national level. Also, the small sample size does not allow to generalize the results.

Moreover, there are other contextual factors that could influence the interpretation of our results such as player positions, player status, match results, match location, and quality of opponents (Oliveira et al., 2020).

In addition, we were also unable to quantify external load within this study which may limit our understanding of the specific types of activity that result in a given internal response (for example, we do not know if a higher s-RPE in a match or training session is due to greater total distance covered or the requirement to repeat more bouts of high-speed running). Therefore, we suggest that future studies would consider such contextual factors. Also, it would be relevant to include some global/local positioning 


\section{Fernandes, R.; Oliveira, R.; Martins, A.; Paulo Brito, J.}

system measures to better understand in internal and external load would relate to each other.

Other suggestion for future studies is to analyze intraand inter-week variations of wellness such as in the study of Nobari, Fani, et al. (2021).

Meanwhile, the present study represented the actual competitive national level from 2019-20 in-season.

\section{CONCLUSIONS \\ AND PRACTICAL APPLICATIONS}

The results showed that there is a higher TL (RPE and s-RPE) on the first and second training sessions of the week (MD-5 and MD-4) than in the last training session (MD-2). Furthermore, matches presented the highest internal workload. Results from HI showed that sleep, fatigue, stress and DOMS was well fair controlled by coaches and staff from the beginning of the microcycle until the MD. This means that TL was adjusted to improve players' wellness until the day of the match.

Through easy, valid and low-cost tools such as the RPE, s-RPE and HI, this study provided relevant information to the staff teams of Portuguese elite women's league clubs to better prepare their athletes for the match, especially for those that trained three times a week. For coaches and practitioners, the study generates reference values for professional players which can be considered when planning training sessions.

\section{DECLARATIONS OF INTEREST}

None.

\section{FUNDING}

This project was supported by the Portuguese Foundation for Science and Technology, I.P., Grant/Award Numbers UIDP/04748/2020.

\section{REFERENCES}

1. Alexiou, H., \& Coutts, A. J. (2008). A Comparison of Methods Used for Quantifying
Internal Training Load in Women Soccer Players. International Journal of Sports Physiology and Performance, 3(3), 320-330. doi:10.1123/ijspp.3.3.320

2. Andersson, H. A., Randers, M. B., Heiner-Møller, A., Krustrup, P., \& Mohr, M. (2010). Elite Female Soccer Players Perform More High-Intensity Running When Playing in International Games Compared With Domestic League Games. Journal of Strength and Conditioning Research, 24(4), 912-919. doi:10.1519/jsc.0b013e3181d09f21

3. Arcos, A. L., Méndez-Villanueva, A., Yanci, J., \& Martínez-Santos, R. (2016). Respiratory and Muscular Perceived Exertion During Official Games in Professional Soccer Players. International Journal of Sports Physiology and Performance, 301-304. https://doi.org/10.1123/ijspp.2015-0270

4. Benjamin, C. L., Hosokawa, Y., Curtis, R. M., Schaefer, D. A., Bergin, R. T., Abegg, M. R., \& Casa, D. J. (2020). Environmental Conditions, Preseason Fitness Levels, and Game Workload. Journal of Strength and Conditioning Research, 34(4),

988-994. doi:10.1519/jsc.0000000000003535

5. Borg, G. (1970). Perceived exertion as an indicator of somatic stress. Scandinavian Journal of Rehabilitation Medicine, 2, 92-98.

6. Burgess, D., Drust, B. \& Williams, M. (2013). Developing a physiology-based sports science support strategy in the professional game. Science and soccer: Developing elite performers, 372-89.

7. Chen, M. J., Fan, X., Moe, S. T. (2010). Criterionrelated validity of the Borg ratings of perceived exertion scale in healthy individuals: a metaanalysis. Journal of Sports Sciences, 20(11), 873899. doi:10.1080/026404102320761787

8. Clemente, F. M., Mendes, B., Bredt, S. d. G. T., Praça, G. M., Silvério, A., Carriço, S., \& Duarte, E. (2019). Perceived Training Load, Muscle Soreness, Stress, Fatigue, and Sleep Quality in Professional Basketball: A Full Season Study. Journal of Human Kinetics, 67(1), 199-207. doi: https://doi.org/10.2478/hukin-2019-0002 


\section{Training and match load quantification in women soccer players}

9. Clemente, F. M., Mendes, B., Nikolaidis, P. T., Calvete, F., Carriço, S., \& Owen, A. L. (2017). Internal training load and its longitudinal relationship with seasonal player wellness in elite professional soccer. Physiology \& Behavior, 179, 262-267.

10. Costa, J., Figueiredo, P., Nakamura, F., Rago, V., Rebelo, A., \& Brito, J. (2019). Intra-individual variability of sleep and nocturnal cardiac autonomic activity in elite female soccer players during an international tournament. PLOS ONE, 14(9), e0218635. doi:10.1371/journal.pone.0218635

11. Datson, N., Drust, B., Weston, M., \& Gregson, W. (2018). Repeated high-speed running in elite female soccer players during international competition. Science and Medicine in Football, 17. doi:10.1080/24733938.2018.1508880

12. Datson, N., Hulton, A., Andersson, H., Lewis, T., Weston, M., Drust, B., \& Gregson, W. (2014). Applied Physiology of Female Soccer: An Update. Sports Medicine, 1225-1240. https://doi.org/10.1007/s40279-014-0199-1

13. Ehrmann, F. E., Duncan, C. S., Sindhusake, D., Franzsen, W. N., \& Greene, D. A. (2016). GPS and injury prevention in professional soccer. Journal of Strength and Conditioning Research, $30(2)$, 360-367. https://doi.org/10.1519/JSC.0000000000001093

14. Emmonds, S., Sawczuk, T., Scantlebury, S., Till, K., \& Jones, B. (2018). Seasonal Changes in the Physical Performance of Elite Youth Female Soccer Players. Journal of Strength and Conditioning Research, doi:10.1519/jsc.0000000000002943

15. Foster, C., Florhaug, J. a, Franklin, J., Gottschall, L., Hrovatin, L. A., Parker, S., ... Dodge, C. (2001). A new approach to monitoring exercise training. Journal of Strength and Conditioning Research / National Strength \& Conditioning Association, 15(1), 109-15. http://doi.org/10.1519/1533-4287

16. Foster, C. (1998). Monitoring training in athletes with reference to overtraining syndrome.
Occupational Health and Industrial Medicine, 4(39), 189. https://doi.org/10.1097/00005768199807000-00023

17. Gabbett, T. \& Mulvey, M. (2008). Time-motion analysis of small-sided training games and competition in elite women soccer players. Journal of Strength and Conditioning Research, 22 , 543-552. https://doi.org/10.1519/jsc.0b013e3181635597

18. Gaudino, P., Marcello, F. I., Strudwick, A. J., Hawkins, R. D., Alberti, G., Atkinson, G., \& Gregson, W. (2015). Factors Influencing Perception of Effort (Session Rating of Perceived Exertion) During Elite Soccer Training. International Journal of Sports Physiology and Performance, $10, \quad 860-864$. https://doi.org/10.1123/ijspp.2014-0518

19. Giménez, JV., Leicht, AS., Gomez, MA. (2019). Physical Performance Differences Between Starter and Non-Starter Players During Professional Soccer Friendly Matches. Journal of Human Kinetics, 69, 283-291. DOI: 10.2478/hukin-2019-0018

20. Halperin, I., \& Emanuel, A. (2020). Rating of Perceived Effort: Methodological Concerns and Future Directions. Sports Medicine, 50(4), 679687. doi:10.1007/s40279-019-01229-z

21. Hooper, S., \& Mackinnon, L. (1995). Monitoring overtraining in athletes. Sports Medicine (5), 321$332 . \quad$ https://doi.org/10.2165/00007256199520050-00003

22. Hopkins, W.G., Marshall, S.W., Batterham, A.M. \& Hanin, J. (2009). Progressive statistics for studies in sports medicine and exercise science. Medicine and Science in Sports and Exercise, 41(1), 3-13. https://doi.org/10.1249/MSS.0b013e31818cb278

23. Impellizzeri, F.M., Marcora, S.M. \& Coutts, A.J. (2019). Internal and external training load: 15 years on. International Journal of Sports Physiology and Performance,14(2), 270-273. Doi:10.1123/ijspp.2018-0935

24. Impellizzeri, F.M., Rampinini, E., Marcora, S.M. (2005). Physiological assessment of aerobic 


\section{Fernandes, R.; Oliveira, R.; Martins, A.; Paulo Brito, J.}

training in soccer. Journal of Sports Science, 23(6), 583-592. https://doi.org/10.1080/02640410400021278

25. Ispirlidis, I., Fatouros, I., Jamurtas, A., Nikolaidis, M., Michailidis, I., Douroudos, I., Margonis, K., Chatzinikolaou, A., Kalistratos, E., Katrabasas, I. \& Alexiou, V. (2008). Time-course of changes in inflammatory and performance responses following a soccer game. Clinical Journal of Sport Medicine, 18, 423-431. https://doi.org/10.1097/JSM.0b013e3181818e0b

26. Kent-Braun, J.A., Ng., A.V., Doyle, J.W. Towse, T. F. (2002). Human skeletal muscle response vary with age and gender during fatigue due to incremental isometric exercise. Journal of Applied Physiology, 93, 1813-1823. https://doi.org/10.1152/japplphysiol.00091.2002

27. Krustrup, P, Mohr, M, Steensberg, A, Bencke, J, Kjær, M, Bangsbo, J. (2006). Muscle and blood metabolites during a soccer game: Implications for sprint performance. Medicine Science in Sports and Exercise, 38, 1165- 1174. https://doi.org/10.1249/01.mss.0000222845.8926 2.cd

28. Krustrup, P., M. Mohr, H. Ellingsgaard, \&Bangsbo, J. (2005). Physical Demands during an Elite Female Soccer Game: Importance of Training Status. Medicine and Science in Sports and Exercise, $37 \quad$ (7),1242-1248. https://doi.org/10.1249/01.mss.0000170062.7398 1.94

29. Krustrup, P., Zebis, M., Jensen, J. M. \& Mohr, M. (2010). Game-Induced Fatigue Patterns in Elite Female Soccer. Journal of Strength and Conditioning Research, 24(2), 437-441. doi:10.1519/jsc.0b013e3181c09b79

30. Malone, J., Di Michele, R., Morgans, R., Burgess, D., Morton, J. P. \& Drust, B. (2015). Seasonal Training-Load Quantification in Elite English Premier League Soccer Players. International Journal of Sports Physiology and Performance, 10(4), 489-497. doi:10.1123/ijspp.2014-0352

31. Manzi, V., D'Ottavio, S., Impellizzeri, F., Chaouachi, A., Chamari, K. \& Castagna C.
(2010). Profile of Weekly Training Load in Elite Male Professional Basketball Players. Journal of Strength and Conditioning Research, 24, 13991406.

https://doi.org/10.1519/JSC.0b013e3181d7552a

32. Matković, B.R., Mišigoj-Duraković, M., Matković, B., Janković, S., Ružić, L., Leko, G., et al. (2003). Morphological differences of elite Croatian soccer players according to the team position. Collegium antropologicum, 27(1), 16774.

33. Mclaren, S. J., Macpherson, T. W., Coutts, A. J., Hurst, C., Spears, I. R. \& Weston, M. (2017). The relationships between internal and external measures of training load and intensity in team sports: a meta-analysis. Sports Medicine, 48(3), 641-658. doi:10.1007/s40279-017-0830-z.

34. McLaren, S. J., Smith, A., Spears, I. R. \& Weston, M. (2016). A detailed quantification of differential ratings of perceived exertion during team-sport training. Journal of Science and Medicine in Sport, 20(3), 290-295. https://doi.org/10.1016/j.jsams.2016.06.011

35. Moalla, W., Fessi, M.S., Farhat, F., Nouira, S., Wong, D.P. \& Dupont, G. (2016). Relationship between daily training load and psychometric status of professional soccer players. Research in Sports Medicine. DOI: 10.1080/15438627.2016.1239579

36. Mohr, M, Ellingsgaard, $\mathrm{H}$, Andersson, $\mathrm{H}$, Bangsbo, J, \& Krustrup, P. (2004). Physical demands in high-level female soccerApplications of fitness tests to evaluate match performance. Journal of Sports Sciences, 22(15), 552-553.

37. Mohr, M, Krustrup, P, Andersson, H, Kirkendal, D, \& Bangsbo, J. (2008). Match activities of elite women soccer players at different performance levels. Journal of Strength and Conditioning Research, 22, 341-349. https://doi.org/10.1519/JSC.0b013e318165fef6

38. Mohr, M, Krustrup, P, Nybo, L, Nielsen, JJ, \& Bangsbo, J. (2004). Muscle temperature and sprint performance during soccer matches-Beneficial 


\section{Training and match load quantification in women soccer players}

effects of re-warm up at half-time. Scandinavian Journal of Medicine Science in Sports, 15, 136143. https://doi.org/10.1111/j.16000838.2004.00349.x

39. Nobari, H., Maryam, F., Clemente, F.M., CarlosVivas, J., Pérez-Gómez, J., Ardigò, L.P. (2021). Intra- and Inter-week Variations of Well-Being Across a Season: A Cohort Study in Elite Youth Male Soccer Players. Frontiers in Psychology, 12, 1030. DOI=10.3389/fpsyg. 2021.671072

40. Nobari, H., Tubagi Polito L.F., Clemente, F.M., Pérez-Gómez, J., Ahmadi, M., Garcia-Gordillo, M.Á., Silva, A.F. \& Adsuar, J.C. (2020). Relationships between training workload parameters with variations in anaerobic power and change of direction status in elite youth soccer players. International Journal of Environmental Research and Public Health, 17(21), 7934. https://doi.org/10.3390/ijerph17217934

41. Oliveira, R., Brito, J.P., Loureiro, N., Padinha, V., Ferreira, B., Mendes, B. (2020). Does the distribution of the weekly training load account for the match results of elite professional soccer players? Physiology \& Behavior, 225, 113118. https://doi.org/10.1016/j.physbeh.2020.113118.

42. Oliveira, R., Brito, J., Martins, A., Mendes, B., Calvete, F., Carriço, S., Ferraz, R. \& Marques, M. (2019a). In-season training load quantification of one-, two- and three-game week schedules in a top European professional soccer team. Physiology \& Behaviour, 201, 146-156. doi: 10.1016/j.physbeh.2018.11.036.

43. Oliveira, R., Brito, J., Martins, A., Mendes, B., Calvete, F., Carriço, S., Ferraz, R., Marques, M. (2019b). In-season internal and external training load quantification of an elite European soccer team. Plos One, 14(4): e0209393.https://doi.org/10.1371/journal. pone.0209393.

44. Peart, A. N., Nicks, C. R., Mangum, M., \& Tyo, B. M. (2018). Evaluation of Seasonal Changes in Fitness, Anthropometrics, and Body Composition in Collegiate Division II Female Soccer Players. Journal of Strength and Conditioning Research,
32(7), 2010-2017. doi:10.1519/jsc.0000000000002578

45. Rabbani, A., Clemente, F.M., Kargarfard, M. \& Chamari, K. (2019). Match Fatigue Time-Course Assessment Over Four Days: Usefulness of the Hooper Index and Heart Rate Variability in Professional Soccer Players. Frontiers in Physiology, $\quad 10,109$ doi: 10.3389/fphys.2019.00109

46. Rebelo, N., Krustrup, P., Soares, J., \& Bangsbo, J. (1998). Reduction in intermittent exercise performance during a soccer match. Journal of Sports Sciences, 16, $482-483$.

47. Scantlebury, S., Till, K., Atkinson, G., Sawczuk, T. \& Jones, B. (2017). The within-participant correlation between s-RPE and heart rate in youth sport. Sports Medicine International Open., 1(06), E195-E199. doi:10.1055/s-0043-118650

48. Scott, D., Norris, D., \& Lovell, R. (2020). DoseResponse Relationship Between External Load and Wellness in Elite Women's Soccer Matches: Do Customized Velocity Thresholds Add Value? International Journal of Sports Physiology and Performance, 15(9), 1245-1251. Retrieved Feb 14, 2021, from https://journals.humankinetics.com/view/journals /ijspp/15/9/article-p1245.xml

49. Stevens, T., Ruiter, C., Twisk, L., Savelsbergh, G. \& Beek, P. (2017). Quantification of in-season training load relative to match load in professional Dutch Eredivisie football players. Science and Medicine in Football, 1(2),117-125, https://doi.org/10.1080/ 24733938.2017.1282163.

50. Stolen. T., Chamari, K., Castagna, C. \& Wisloff, U. (2005). Physiology of soccer: an update. Sports Medicine, 35 , 501-36. https://doi.org/10.2165/00007256-20053506000004

51. Thorpe, R. T., Strudwick, A. J., Buchheit, M., Atkinson, G., Drust, B., \& Gregson, W. (2016a). The Influence of Changes in Acute Training Load on Daily Sensitivity of Morning-measured Fatigue Variables in Elite Soccer Players. International Journal of Sports Physiology and Performance, 


\section{Fernandes, R.; Oliveira, R.; Martins, A.; Paulo Brito, J.}

12(2), S2107-S2113. doi: 10.1123/ijspp. 20160433

52. Thorpe, R., Strudwick, A., Buchheit, M., Atkinson, G., Drust, B., \& Gregson, W. (2015). Monitoring fatigue during the in-season competitive phase in elite soccer players. International Journal of Sports Physiology and Performance, 10, 958-964. doi: 10.1123/ijspp. 2015-0004

53. Thorpe, R.T., Strudwick, A. J., Buchheit, M., Atkinson, G., Drust, B., \& Gregson, W. (2016b). Tracking Morning Fatigue Status Across In-
Season Training Weeks in Elite Soccer Players. International Journal of Sports Physiology and

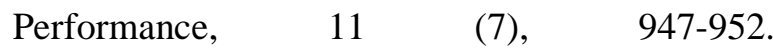
https://doi.org/10.1123/ijspp.2015-0490

54. Wright, M. D., Songane, F., Emmonds, S., Chesterton, P., Weston, M., \& Mclaren, S. J. (2020). Differential ratings of perceived match and training exertion in youth female soccer. International Journal of Sports Physiology and Performance. DOI: 10.1123/ijspp.2019-0595 